\begin{tabular}{|c|c|c|c|}
\hline KULTURA & $\begin{array}{l}\text { POLSKA } \\
\text { KOMITET } \\
\text { INSTYTU }\end{array}$ & $\begin{array}{l}\text { AKADEMIA NAUK } \\
\text { SOCJOLOGII } \\
\text { T STUDIÓW POLITYCZNYCH }\end{array}$ & $\frac{\text { ISSN 0023-5172 }}{\mathrm{I}}$ \\
\hline SPOLECLESTM & 2015, nr 1 & CZYTAJĄC ELIASA & \\
\hline
\end{tabular}

JOANNA ZALEWSKA

Akademia Pedagogiki Specjalnej im. Marii Grzegorzewskiej

\title{
REWOLUCJA KONSUMPCYJNA I KSZTAŁTOWANIE SIĘ PODMIOTU EMOCJONALNEGO W PERSPEKTYWIE NORBERTA ELIASA
}

Współzależność procesów zachodzących w społeczeństwie i struktur psychicznych należących doń jednostek była podstawową zasadą podejścia badawczego Norberta Eliasa $(1980,2011)$. W dziele O procesie cywilizacji. Analizy socjo- $i$ psychogenetyczne (2011) [Über den Prozeß der Zivilisation, 1939] Elias analizował procesy decydujące o zmianach, którym ulegały społeczeństwa zachodnie, czyli socjogenezę państwa nowoczesnego i ściśle z nią powiązany proces cywilizowania, czyli racjonalizacji zachowań jednostek. Na podstawie materiałów historycznych studiował zachodzący w Europie Zachodniej między VIII a XVIII wiekiem proces monopolizacji władzy, przejawiający się w skupianiu w jednym ręku monopolu na użycie przemocy i monopolu na pobieranie podatków. Proces ten był związany z powstawaniem w średniowiecznym społeczeństwie enklaw gospodarki pieniężnej, dzięki ukonstytuowaniu się stanu trzeciego - mieszczaństwa, co umożliwiło bogacenie się rodom feudalnym, posiadającym największe obszary ziemi i skupiającym wokół swych zamków osady, a potem miasta. Procesowi monopolizacji towarzyszył wzrost zależności pomiędzy wszystkimi mieszkańcami terytorium objętego monopolem, co w ostateczności doprowadziło do uspołecznienia monopolu — upadku monarchii i powstania państw narodowych. Proces monopolizacji na pewnych terenach europejskich zachodził szybciej (Francja), na innych wolniej (Niemcy), postępował i cofał się, jednakże samo kształtowanie się monopolu i cywilizowanie żyjących w zasięgu jego oddziaływania jednostek Elias uważał za procesy nieuchronne. Przewidywał (Elias 2008, s. 192-200), że na Ziemi będą powstawać coraz większe obszary integracji, które nazywał jednostkami przetrwania. 
Sądził, że obecnie jesteśmy na drodze do wykształcenia się jednostki przetrwania na poziomie całej ludzkości.

Współcześnie rywalizacja między jednostkami zachodzi tylko w sferze ekonomicznej, dzięki temu, że państwa mają monopol na przemoc fizyczną, co usuwa zagrożenie bezpośrednich walk między rywalizującymi (Elias 2011). W momencie, w którym Elias kończy swoją analizę: gdy monopol na użycie przemocy i pobieranie podatków przechodzi z rąk monarchy $\mathrm{w}$ ręce obywateli, a konkretnie burżuazji, czyli w momencie ukonstytuowania się państwa nowoczesnego, studia rozpoczynają historycy ekonomiczni i socjologowie — zauważają, że w tym okresie dokonała się tzw. rewolucja konsumpcyjna. Rewolucja konsumpcyjna jest pojęciem, za pomocą którego — podobnie jak w teorii Eliasa - próbuje się połączyć dwa porządki: makro- i mikrospołeczny. Składające się na nią procesy są bowiem odpowiedzialne za popyt na dobra produkowane masowo dzięki rewolucji przemysłowej. Rewolucja konsumpcyjna jest to rozprzestrzenienie się gospodarki pieniężnej na wszystkie sektory społeczeństw zachodnich, czemu towarzyszy rozwój rynków narodowych (McKendrick, Brewer, Plumb 1982), które stają się areną walk o monopol w sferze ekonomicznej.

Rewolucja konsumpcyjna wiąże się również z przemianą struktury psychicznej jednostki, z postępowaniem — analizowanego przez Eliasa — procesu racjonalizacji, która zaczyna dotyczyć również sfery emocji. W okresie opisywanym przez Eliasa emocje i popędy były wytłumiane i spychane do podświadomości. Pisząc o genezie rewolucji konsumpcyjnej Colin Campbell (1987) twierdzi, że emocje przestają być traktowane jako zewnętrzne siły targające człowiekiem, zostają umiejscowione we wnętrzu jednostki, a ich odczuwanie ma przynosić jednostkom indywidualną przyjemność. Tę przemianę od wytłumiania i spychania do podświadomości do otwartego wyrażania emocji można wytłumaczyć za pomocą Eliasowskiej analogii stosunku do spania. W XIX wieku czynność spania jako potrzeba fizjologiczna była ukryta $\mathrm{w}$ prywatnej strefie sypialni. Zmieniło się to $\mathrm{w}$ XX wieku i - jak wskazuje Elias - nie wynika z cofnięcia się procesu cywilizowania, lecz wręcz przeciwnie. Społeczeństwo stworzyło odpowiednie formy pozwalające ucywilizować to zachowanie, czyli piżamy. Podobnie można myśleć o emocjach: w XVIII wieku na dworze królewskim były wytłumiane, w XX wieku zaś stały się otwarcie wyrażane, ponieważ powstały odpowiednie formy, by je ucywilizować.

Opisywana przez Eliasa (2011) stopniowa przemiana struktury psychicznej jednostek, która wiązała się ze wzrostem samokontroli i podniesieniem progu wstydu, odpowiada za zachodzący od końca średniowiecza proces cywilizowania. $\mathrm{Na}$ dworze królewskim rodziły się coraz bardziej wyrafinowane formy zachowania, jak jedzenie widelcem i używanie chusteczki do nosa. Rywalizacja kulturowa między słabnącą pod względem ekonomicznym arystokracją i bogacącą się burżuazją powołała do życia modę. Gdy tylko przedstawiciele burżuazji zaczynali naśladować zdobycze cywilizacyjne arystokracji, członkowie arystokracji znajdowali nowe formy wyrazu, by się odróżnić. W procesie 
rewolucji konsumpcyjnej moda objęła wszystkie warstwy społeczne, stając się instrumentem rywalizacji między członkami społeczeństw nowoczesnych.

Moim celem jest analiza ważnego momentu rewolucji konsumpcyjnej w Polsce - okresu po drugiej wojnie światowej, kiedy duże grupy ludności przenosiły się ze wsi do miast, znajdując zatrudnienie w przemyśle. Władze Polski Ludowej wdrażały nowe technologie w przemyśle i w mieszkalnictwie, propagowały ideologię postępu, która realizować się miała w rozwiązaniach technologicznych i społecznych służących podnoszeniu poziomu życia ludności. Obok racjonalnych argumentów wytaczanych przez władze zainteresowanie innowacjami podsycały przekazy docierające $z$ Zachodu mimo żelaznej kurtyny. W latach sześćdziesiątych XX wieku, gdy w Polsce upowszechniała się telewizja, transmitowano w niej amerykańskie filmy. Pokazywany w nich standard życia i praktyki nakierowane na odczuwanie indywidualnych emocji były atrakcyjne dla polskiej publiczności. Kultura konsumpcyjna - rodząca się najpierw w pragnieniach i marzeniach - dla mieszkańca Polski stanowiła płaszczyznę porozumienia z mieszkańcami krajów zachodnich. Warto zastanowić się, czy kultura konsumpcyjna i rynek stanowią główną płaszczyznę, na której dokonuje się proces integracji ludzkości. Opierając się na badaniach jakościowych, które przeprowadziłam wśród przedstawicieli starszych pokoleń, urodzonych w latach 1918-1942, spróbuję pokazać, że można zaobserwować pokoleniowe różnice struktury psychicznej jednostek, odzwierciedlające zmiany społecznych poziomów integracji.

\section{REWOLUCJA KONSUMPCYJNA W PERSPEKTYWIE NORBERTA ELIASA}

Mechanizm kształtowania się monopolu według Eliasa (2011, s. 385-386) można streścić w następujący sposób: jeśli w obrębie danej społeczności określona pula środków utrzymania i produkcji nie wystarcza do zaspokojenia potrzeb ludzkich, toczy się o nią walka konkurencyjna. Jeśli założymy, że rywalizujące jednostki mają mniej więcej taką samą siłę, to początkowo walka ma charakter wolnej konkurencji. Jednakże prawdopodobieństwo, że równowaga utrzyma się przez długi czas, jest bardzo małe, a prawdopodobieństwo, że po pewnym czasie część uczestników zostanie wyeliminowana, bardzo duże. Następnie rywalizacja będzie się toczyć między tymi jednostkami, które pozyskały środki utrzymania i produkcji kosztem konkurentów. Zjawisko monopolizacji wystąpi ponownie, aż do czasu, gdy wyłoni się jeden zwycięzca, który skupi wszystkie zasoby w jednym ręku, uzależniając od siebie pozostałych uczestników rywalizacji.

Historycy ekonomiczni (McKendrick, Brewer, Plumb 1982) argumentuja, że intensywna i szeroka komercjalizacja nastąpiła w osiemnastowiecznej Anglii. Powstał rynek masowy, z którego wyłączeni byli właściwie tylko robotnicy rolni. W Anglii proces ten przebiegał szybciej i sprawniej niż w innych krajach europejskich. Wolną konkurencję i związaną z nią znaczną egalitarność 
warstwy mieszczańskiej obrazuje fakt, że na ulicach ówczesnych miast trudno było zaobserwować różnice stanowe. Wszyscy ubierali się zgodnie z najnowszą modą. Trendy w modzie, które jeszcze na początku XVIII wieku kształtowane były przez Paryż, co symbolizowała fashion doll - drewniany manekin wielkości człowieka, który co roku sprowadzano z Francji na dwór królewski zaczęły być kreowane przez miejscowych przedsiębiorców na potrzeby masowego rynku, co z kolei symbolizuje mała fashion doll - angielska, zrobiona $z$ tektury i sprzedawana wszystkim stanom za grosze. Co ciekawe, wzrost wydatków gospodarstw domowych, który historycy szacują na 370\%, w niewielkim stopniu realizował się poprzez faktyczne transakcje pieniężne. Borykano się z niewystarczającym wolumenem pieniądza i często sięgano po kredyt lub zaciągano pożyczki. Odwołując się do mechanizmu kształtowania się monopolu, możemy mówić o niewystarczającej puli środków utrzymania i produkcji. Pożyczek udzielali bogatsi członkowie społeczności, którzy na tym dalej się bogacili, choć często mieli kłopoty z egzekwowaniem długów. Widzimy tu analogię do procesu opisanego przez Eliasa (2011): nadawania ziemi przez panów feudalnych, którzy chcieli rosnąć w siłę dzięki posiadaniu wasali, ale w praktyce często ich tracili, ponieważ owo nadawanie zmniejszało ich potęgę. Osiemnastowieczni angielscy przedsiębiorcy różnych sektorów i szczebli zrzeszali się w kluby, które pomagały swym członkom w przypadku konieczności spłaty zadłużenia, ale także prowadziły działalność wspierającą wolny handel w miejsce usług na rzecz arystokracji i ziemiaństwa. W tej perspektywie rewolucja konsumpcyjna była momentem rozpoczęcia wolnej konkurencji w sferze ekonomicznej, dzięki dostępowi większości społeczeństwa do rynku pieniężnego. Stanowiła element walki mieszczaństwa przeciwko arystokracji, która do tej pory była głównym odbiorcą krążących na rynku dóbr luksusowych. Produkowanie dóbr dla mieszczańskiego konsumenta wyzwalało mieszczańskich wytwórców z podległości wobec arystokracji ${ }^{1}$.

Arjun Appadurai (2005) definiuje rewolucję konsumpcyjną jako zmianę społecznie zorganizowanych form konsumpcji: od zakazu w małych izolowanych społecznościach lub od prawnych ograniczeń konsumpcji (sumptuary law) w społeczeństwach feudalnych do mody opartej na zasadzie społecznego naśladownictwa (social emulation). Wiąże ją z takimi cechami jak mobilność społeczna, wzrost płac, wyrafinowany marketing i reklama, wzrost masowego handlu, konflikt klasowy, znajomość pisma i rachunków, wiedza ekspercka, handel książkami, inne formy skomercjalizowanej informacji.

Neil McKendrick (1982) uważa, że główną przyczyną rewolucji konsumpcyjnej była działalność przedsiębiorców w zakresie marketingu i reklamy. Przedsiębiorcy za pomocą marketingu stymulowali zmiany mody, by wzmagać popyt

${ }^{1}$ Podobne przemiany występowały w systemie sztuki, gdzie artysta przestawał być podległy panom feudalnym jako mecenasom, a stawał się profesjonalistą tworzącym dla publiczności na wolnym rynku (Elias 2006). 
na swoje dobra: dawali prezenty na dworze, reklamowali się jako popierani przez ludzi dworu. Podążanie za modą można więc postrzegać jako konsumpcję statusową (Veblen 2008). Za Eliasem można wnioskować, że w rywalizacji ekonomicznej brało udział niemal całe społeczeństwo. Tak jak w społeczeństwie feudalnym żaden posiadacz nie mógł zaprzestać ekspansji na nowe ziemie, by nie zostać pokonanym przez sąsiadów, tak w osiemnastowiecznej Anglii wszyscy mieszczanie musieli podążać za modą.

Colin Campbell (1987) przyczyn rewolucji konsumpcyjnej upatruje nie w mechanizmach komercjalizacji, lecz w zmianie mentalności burżuazji. Mieszczanie nie aprobowali sposobu życia arystokracji, ceniąc rzetelność, pożyteczność, pobożność. Zgodnie z purytańską etyką ganili życie pełne ziemskich uciech. W związku z tym $\mathrm{w}$ warstwie mieszczańskiej wykształcił się nowoczesny hedonizm: w miejsce oddawania się zmysłowym przyjemnościom nastawienie dzięki wyobraźni pozwalające przydać każdemu doświadczeniu element przyjemności. Przyjemność dawało zatem przede wszystkim odczuwanie różnego rodzaju emocji. Kształtowanie się takiej struktury psychicznej Campbell wnikliwie analizuje, próbując uzupełnić dzieło Maksa Webera (2011), który badał genezę etyki przedsiębiorczości, by zrozumieć powstanie nowej wrażliwości - etyki romantycznej. W etykę protestancką — zwłaszcza $\mathrm{w}$ nurcie pietyzmu - wpisane było przekonanie, że cnota związana jest z dobrymi uczuciami. Wrażliwość i emocjonalność, wyrażające się poprzez melancholię i współczucie, to znaki łaski Boga. Człowiek rozwijający w sobie uczucia moralne: życzliwość i współczucie, odczuwał przyjemność, widząc, że jest do tego zdolny, czyli należy do grona obdarzonych łaską. Uczucia początkowo odczuwane głównie w sferze religijnej zaczęly dotyczyć całego doświadczenia. W ten sposób zrodził się sentymentalizm - kult wrażliwości.

Jeśli na spór między McKendrickiem a Campbellem o genezę rewolucji konsumpcyjnej spojrzymy w kategoriach Eliasa, to możemy uznać go za bezzasadny. Rozwój rynku, czyli komercjalizacja powodowana rywalizacją ekonomiczną, oraz zmiana struktury psychicznej jednostek, polegająca na uwewnętrznieniu emocji i stymulowaniu ich w codziennych doświadczeniach w celu odczuwania przyjemności, to procesy współzależne na poziomie socjo- i psychogenezy. Poszukiwanie przyjemności poprzez stymulację emocji jest jednocześnie mechanizmem brania udziału w rywalizacji o prestiż, którego oznaki to bogactwo i nadążanie za modą. Wynika $z$ tego, że model konsumpcji, przez Campbella (2005) nazwany modelem Veblena-Simmla, w którym konsumpcja służy okazaniu i podniesieniu statusu, i model opisany przez niego samego, w którym konsumpcja służy przyjemności, stanowią dwie strony tej samej monety. Model Veblena-Simmla odzwierciedla przede wszystkim logikę makrostrukturalną mechanizmu, a model Campbella logikę psychologiczną.

Masowa konsumpcja w XX wieku objęła całe społeczeństwa zachodnie. $\mathrm{Na}$ początku ery fordyzmu w Stanach Zjednoczonych czynnikami powstania rynku masowego były: produkcja masowa, wysokie płace robotników, przemysł re- 
klamowy, możliwość uzyskania kredytów i kupna na raty. Instrumentom tym towarzyszył interwencjonizm państwowy, pozwalający na utrzymanie pełnego zatrudnienia (Aldridge 2006). W kontynentalnej Europie Zachodniej, zdaniem Victorii De Grazia (2005), robotnicy stali się konsumentami na rynku dopiero po drugiej wojnie światowej, w okresie rozwoju państwa opiekuńczego i upowszechnienia możliwości kupna na raty. Rynki masowe rozkwitły, gdy państwo regulowało stosunki rynkowe (Lewicki 2012) i gdy rozwinęły się instytucje finansowe oferujące kredyty. Ważnymi podmiotami na rynkach masowych były państwa - regulujące tę sferę, banki udzielające kredytów i przedsiębiorstwa produkujące dobra i usługi. Elias porównywał państwa do panów feudalnych — ze względu na możliwość stosowania przemocy we wzajemnych stosunkach i monopol na przemoc wobec obywateli. Banki i przedsiębiorstwa funkcjonalnie można porównać do bogatego mieszczaństwa. Proces kształtowania się monopolu ekonomicznego w tym okresie był już zaawansowany, większość środków pozostawała $\mathrm{w}$ gestii międzynarodowych korporacji, głównie amerykańskich, co - zdaniem Eliasa - wskazywało na zamożność i dominację Stanów Zjednoczonych Ameryki jako państwa powoli uzyskującego monopol w procesie integracji na poziomie ludzkości².

\section{MODA I PSYCHOGENEZA PODMIOTU EMOCJONALNEGO}

Według koncepcji Eliasa wzrostowi zależności międzyludzkich na danym poziomie integracji będzie towarzyszyć przebudowa psychiczna jednostek, związana ze wzrostem ich autoregulacji. W społeczeństwie dworskim sukces zależał od wkupienia się w łaskę króla i umiejętnego współżycia $z$ innymi dworzanami (Elias 2011). Rozwijała się psychologizacja, czyli zdolność postrzega-

\footnotetext{
2 Analiza staje się trudniejsza po latach osiemdziesiątych XX wieku, kiedy na skutek rozwoju nowych technologii doszło do globalizacji rynku i deregulacji rynków lokalnych, czyli wycofania kontroli państw. Zamożność danej korporacji nie przekłada się już bezpośrednio na zamożność państwa i jego obywateli. Korporacje działają niezależnie i globalnie. Rynki funkcjonują jako sieci zintegrowane globalnie, transakcje i przepływy toczą się bardzo szybko (Castells 2010). Manuel Castells (2009) uważa, że obecnie wartość jest tworzona na rynkach finansowych i tam jest akumulowany największy kapitał. Być może więc obecnie to sieci rynku finansowego w rywalizacji o monopol finansowy pełnią funkcję analogiczną do eliasowskiego króla (dziękuję Dariuszowi Jażdżykowi za ten pomysł interpretacyjny), a państwa to odsunięta od walk konkurencyjnych szlachta? Proces monopolizacji kapitału jest zaawansowany, walka toczy się między najbogatszymi, którzy zmonopolizowali większość zasobów. Świadczy o tym duże i wciąż pogłębiające się rozwarstwienie ekonomiczne. O ile w erze fordyzmu walczące o monopol korporacje były zależne od swoich pracowników, o tyle obecnie - ze względu na automatyzację i redukcję personelu większości branż, a także wysycenie rynków Europy Zachodniej około roku 1979 (Rifkin 2001) - są zależne raczej od konsumentów. Możliwości upubliczenienia monopolu można oczekiwać wraz ze spadkiem siły nabywczej konsumentów, co będzie postępowało wraz z procesem gromadzenia coraz większej puli środków utrzymania i produkcji przez coraz węższą grupę. Można sądzić, że upubliczenienie monopolu będzie możliwe dopiero wtedy, gdy niski popyt na oferowane przez korporacje dobra i dostęp do nich (Rifkin 2003) będzie zagrażał ich funkcjonowaniu.
} 
nia innych ludzi jako posiadających indywidualne „wnętrza”: cechy charakteru, motywacje, związana z próbą przejrzenia celów i motywów konkurentów o łaskę u króla. Postępowała również racjonalizacja, czyli rosła umiejętność przewidywania zdarzeń i planowania własnego postępowania. Średniowieczny rycerz do pewnych ludzi i zdarzeń odczuwał silne emocje pozytywne, a do innych silne emocje negatywne, łatwo mógł przechodzić od jednego stanu emocjonalnego do innego. Dworzanin miał bardziej złożony i ambiwalentny stosunek do każdego człowieka i zdarzenia. Emocje uległy osłabieniu i były niejednoznaczne wobec danego obiektu, co wynikało ze złożoności łączących z nim powiązań.

O ile w warstwie arystokracji doszło do tłumienia emocji i spychania ich do podświadomości, o tyle wśród burżuazji rozpoczął się proces „obróbki” emocji i otwartego wyrażania emocji ucywilizowanych. Proces ten był - jak interpretuje to Campbell — ważnym mechanizmem rewolucji konsumpcyjnej, która wówczas zachodziła. Tutaj nazywam go racjonalizacją emocji, używając określenia ukutego przez Evę Illouz (2010). Mam na myśli fakt, że emocje automatycznie nie prowadzą do działania, lecz stają się przedmiotem, na który zwraca uwagę podmiot jako strumień świadomości, i albo się nimi delektuje, albo je werbalizuje, albo nawet analizuje. W każdym przypadku są one już choć trochę zracjonalizowane - uprzedmiotowione przez procesy myślowe.

Cas Wouters $(2004,2007)$ analizuje proces tzw. odformalizowania stosunków międzyludzkich. Stawia tezę, że w XX wieku coraz bardziej otwarcie można było wyrażać większość emocji oraz zmniejszały się dystanse społeczne i psychiczne między ludźmi z różnych klas społecznych i o różnej płci, co wiązało się ze wzrostem autoregulacji emocji. Odformalizowanie nie było procesem jednorodnym, postępowało i cofało się. Co ciekawe, momenty jego nasilenia korespodują z okresami wzmożonego oddziaływania tzw. etyki romantycznej i wzrostu konsumpcji (Campbell 1987), co może sugerować, że chodzi o ten sam proces wzmożenia wyrażania indywidualnych emocji i kierowania się nimi $\mathrm{w}$ codziennym życiu co $\mathrm{w}$ rewolucji konsumpcyjnej zapoczątkowanej w warstwie burżuazji. Sądzić można, że emocje są odpowiedzialne za podążanie za modą, co umożliwia utrzymanie spoistości społecznej na wysokim poziomie integracji, tak jak w kapitalistycznym społeczeństwie konsumpcyjnym.

Mechanizm nowoczesnego hedonizmu czyni nowoczesne jednostki podatnymi na prawa mody. Działa w ten sposób, że jednostka wyobraża sobie siebie w podobnych sytuacjach jak te prezentowane na przykład na witrynach domów handlowych, co wyzwala różne emocje - związane $z$ indywidualnymi potrzebami i pragnieniami - i rodzi chęć nabycia danego towaru (Campbell 1987, 2005; Illouz 2009). We wczesnonowoczesnym społeczeństwie moda została zinstytucjonalizowana. Powstały wyspecjalizowane instytucje, które regularnie w odstępach sezonowych narzucały nowy styl (Lipovetsky 1987). Moda w zakresie strojów była najłatwiej zauważalna, ale te same prawidłowości (Lipovetsky 1987; McKendrick, Brewer, Plumb 1982) dotyczyły całego rynku dóbr 
i usług, zwłaszcza dóbr luksusowych i usług związanych z czasem wolnym, a także - wraz z rozwojem mediów - filmów, muzyki. Popularność programów, gwiazd, zespołów również wpisana była w rytm mody. Tak funkcjonująca modę nowoczesną z jednym centrum oddziaływania Lipovetsky nazywał mode de cent ans, gdyż narodziła się pod koniec XIX wieku i obowiązywała przez około stu lat.

Jednym z pierwszych wydarzeń przełamujących modę stuletnią była moda na jeansy, która do haute couture wkroczyła z kultury młodzieżowej stymulowanej filmami produkowanymi w Hollywood. Wraz z rozwojem rynków globalnych powstała tzw. moda horyzontalna, która ma wiele centrów (Strzyczkowski 2012), trudne do określenia kierunki przepływów i rytm szybkich nieregularnych zmian. Wymaga od jednostek większej elastyczności. Już nie uczucia lub w miarę stałe emocjonalne wyobrażenia kierują konsumentami. Coraz ważniejsze stają się chwilowe emocje. Jednostka robi coś lub wybiera coś dlatego, że $\mathrm{w}$ danym momencie czuje się z tym dobrze. Tak rodzi się dominacja teraźniejszości w kulturze współczesnej (Bauman 2009; Tarkowska 2013).

Stymulowanie występowania emocji, które mają przynieść przyjemność, jest realizowane nie tylko w sferze rynku. W każdym społeczeństwie istnieją pewne reguły określające, $w$ jakich sytuacjach, jakie emocje są odpowiednie. Jednostka musi wykonać pracę emocjonalną, by swoje uczucia do tych wymogów dostosować (Hochschild 2009). We współczesnych społeczeństwach zachodnich mamy sytuację o tyle wyjątkową, że jednostka może wyrażać swoje indywidualne emocje, nie musi już wpisywać się w schematy wynikające $z$ sytuacji. Wolność do ekspresji indywidualnych emocji i ukierunkowanie postępowania za ich pomocą rozprzestrzeniały się na wszystkie sfery życia społecznego. Pierwszą sferą było życie rodzinne. Rozkwit miłości romantycznej jako pobudki do zawierania małżeństwa został zapoczątkowany w warstwie burżuazji (Campbell 1987; Giddens 2007; Kaufmann 2012). Nowa wrażliwość, zrodzona $\mathrm{w}$ kontekście stosunków z Bogiem, została przeniesiona zarówno w sferę konsumpcji, jak i stosunków damsko-męskich (Gergen 2009). Czytelnictwo powieści romantycznych stymulowało zapewne złożone wyobrażenia na temat życia, w których główną rolę grał ukochany, ale istotna była również sceneria - wyposażenie domu, stroje.

W życiu rodzinnym opartym na uczuciach znaczącym dystraktorem są emocje negatywne, które trudniej niż pozytywne poddać cywilizowaniu. Można sądzić, że na to zapotrzebowanie odpowiadał rozwój psychoanalizy w XIX wieku, adresowany głównie do osób z rodzin klasy średniej, budowanych dzięki uczuciom. Celem psychoanalizy jest racjonalizacja emocji poprzez werbalizowanie ich (Illouz 2010). Poszukiwanie i odkrywanie emocji negatywnych w trakcie psychoterapii świadczy o skutecznym wytłumieniu ich w procesie racjonalizacji opisanym przez Eliasa. Być może trudniejsze do okiełznania emocje negatywne częściej były tłumione, a pozytywne wykorzystywane w mechanizmie nowoczesnego hedonizmu. 
Kolejną sferą, w której emocjonalność zyskała na znaczeniu, była sfera pracy. Illouz (2010) analizuje, w jaki sposób zalecenia stosowane w pracy psychoanalitycznej były adaptowane jako elementy pracy menadżera. Słuchanie, parafraza, empatia stały się podstawowymi kompetencjami pracownika korporacji i pod postacią inteligencji emocjonalnej zostały poddane parametryzacji.

Współczesna socjologia koncentruje się na badaniu tzw. nowych form wspólnotowości, czyli grup, które łączy współodczuwanie i dzielenie się emocjami (Maffesoli 2008; Olcoń-Kubicka 2009). Bycie razem stymuluje emocje, które dostarczają jednostce przyjemności, i umożliwia ich wyrażanie wobec innych. Również aktywność młodych ludzi na portalach społecznościowych $\mathrm{w}$ internecie jest motywowana chęcią ekspresji emocji, które ukierunkowują podejmowane tam działania komunikacyjne (Halawa 2013).

W późnej nowoczesności zakończył się historyczny proces wytwarzania podmiotu (Kaufmann 2013), czyli autoregulującej się jednostki. W procesie psychologizacji, racjonalizacji oraz racjonalizacji emocji człowiek uzyskał głębokie „wnętrze”. Taka wizja jest wytwarzana przez instytucje, techniki i wzory, które nazywane są kulturą indywidualizmu (Jacyno 2007). Jednakże to „wnętrze" w rzeczywistości nie jest obiektywną substancją, jest procesem, polega na ciągłym wyobrażaniu sobie siebie oraz iluzorycznym kreowaniu jedności na bazie rozproszonego strumienia świadomości (Kaufmann 2013). Ja kieruje się emocjami, które rodzą się w jego wyobrażonym wnętrzu, czyli jest podmiotem emocjonalnym: „podstawowym czynnikiem ukierunkowującym działania jednostki stają się jej indywidualne i zsubiektywizowane odczucia, uczucia i emocjonalne przeżycia" (Marody 2014, s. 205).

\section{KSZTAŁTOWANIE SIĘ MODY I PODMIOTU EMOCJONALNEGO W POLSCE LUDOWEJ}

Po powyższej próbie zarysowania współzależności między procesem integracji społecznej a przekształceniami struktury Ja skoncentruję się na rozwoju rynku masowego, mody i podmiotu emocjonalnego w Polsce Ludowej, by bliżej przyjrzeć się współzależności między procesami socjo- i psychogenetycznymi. Po drugiej wojnie światowej w Polsce Ludowej mieliśmy do czynienia - podobnie jak w walce między arystokracją i burżuazją $-\mathrm{z}$ rywalizacją postawy racjonalnej i emocjonalnej, tyle że postawy te miały inne konotacje i były wpisane w inny porządek strukturalny. Przed drugą wojną światową 70\% ludności Polski żyło na wsi, funkcjonując $\mathrm{w}$ większości w warunkach gospodarki naturalnej (Tomaszewski 1996). W tradycyjnych społecznościach zachowanie było regulowane przez normy obyczajowe (Kwaśniewicz 1981). Obyczaj i moda to dwa podstawowe rodzaje więzi społecznej oparte na naśladownictwie, zakładające odmienne formy temporalności (Lipovetsky 1987). Moda — jak już wiemy - to naśladowanie współczesnych i zewnętrznych wzorów, obyczaj to naśladowanie przodków i starszych w społeczności. 
Po wojnie Polska znalazła się pod kuratelą ZSRR, wprowadzono ustrój socjalistyczny i znacjonalizowano gospodarkę. Mimo to występowała większość czynników rewolucji konsumpcyjnej. Władze Polski Ludowej postawiły na przemysł ciężki. Norman Davies (1994) określa powojenną industrializację mianem drugiej rewolucji przemysłowej w Polsce. Miały miejsce masowe wewnętrzne migracje, młodzież wiejska znajdowała zatrudnienie $\mathrm{w}$ przemyśle $\mathrm{w}$ miastach i zaczynała uczestniczyć w gospodarce pieniężnej. Pod koniec lat czterdziestych mieszkańcy wsi stanowili dwie trzecie populacji, w latach sześćdziesiątych poniżej 50\% (Okólski 2002). Uprzemysłowieniu towarzyszyły likwidacja analfabetyzmu $\mathrm{w}$ warstwie przedwojennych chłopów (GUS 1956) i propaganda postępu, która była integralnym elementem ideologii socjalistycznej (Bauman 1995). W latach pięćdziesiątych obieg czasopism był dwa i pół raza wyższy niż przed wojną (Kłoskowska 1964). Najłatwiej nowe idee internalizowała młodzież i przedwojenne warstwy chłopskie, dla których stanowiły one pierwszy kod abstrakcyjnego myślenia, tłumaczący powojenny awans w kategoriach walki klasowej i postępu (Świda-Ziemba 1998).

Brakowało podstawowego czynnika - rywalizacji ekonomicznej: wolnego handlu, reklamy i marketingu. Jeden podmiot — państwo - był zarówno producentem, jak i dystrybutorem towarów, usług i informacji. Druga rewolucja przemysłowa $\mathrm{w}$ Polsce odznaczała się niedoinwestowaniem sektora towarów konsumpcyjnych (Davies 1994) w porównaniu z sytuacją w krajach zachodnich. Wzrost konsumpcji następował głównie w dawnej warstwie chłopskiej (GUS 1956). Rynek narodowy nie rozwijał się, po znacjonalizowaniu gospodarki liczba sklepów detalicznych znacząco spadła. Powojenne racjonowanie żywności kontynuowano aż do 1953 roku pod postacią uprzywilejowania dostępu do pewnych dóbr dla wybranych branż zawodowych.

Mimo żelaznej kurtyny Polacy wiedzieli, chociażby dzięki powojennej pomocy Narodów Zjednoczonych (UNRRA) czy paczkom od rodzin z zagranicy, $\dot{z}$ e w krajach zachodnich standard życia jest wyższy. Symbolem amerykańskiego standardu życia były, kojarzone z luksusem, coca-cola i guma do żucia. Tak zwane ciuchy, czyli ubrania pochodzenia zachodniego, rozprowadzano $\mathrm{w}$ ramach gospodarki nieformalnej. Najpopularniejszy tygodnik „Przekrój” przemycał nowinki z Zachodu. Pod koniec lat czterdziestych, gdy jeszcze prawie nikt $\mathrm{w}$ Polsce nie mógł sobie pozwolić na samochód, pismo zapoczątkowało cykl artykułów Czar czterech kótek, szerząc marzenia i wiedzę na temat samochodów (Jaworska 2008). Treści publikowane w magazynie pełniły rolę reklamy ważnego czynnika rewolucji konsumpcyjnej w krajach zachodnich. Funkcję tę w latach sześćdziesiątych zdominowała telewizja. Na początku tej dekady oglądali ją ludzie młodzi w dużych miastach i inteligencja, pod koniec - wszyscy. W telewizji transmitowano wówczas dużo amerykańskich filmów. Przeciętny Polak pragnął wyglądać i żyć tak, jak ludzie po drugiej stronie ekranu (Pleskot 2007). Te marzenia miały okazję się zrealizować dopiero w latach siedemdzie- 
siątych, gdy pierwszym sekretarzem PZPR został Edward Gierek, który zaciągnął pożyczki w państwach zachodnich i importował zachodnie technologie do produkcji artykułów konsumpcyjnych (Davies 1994).

Do końca lat sześćdziesiątych rozwinął się w Polsce mechanizm mody ${ }^{3}$, pierwszym impulsem były działania władz związane $z$ industrializacją i rozwojem gospodarki pieniężnej, a także z propagowaniem ideologii postępu. Jednakże kluczowe znaczenie miały, jak się wydaje, przekazy z Zachodu, kształtujące wyobraźnię Polaków. Ażeby przyjrzeć się bliżej, jak moda rozwijała się i jaką rolę odgrywały $\mathrm{w}$ tym procesie pozytywistyczna ideologia postępu i etyka romantyczna, poddam analizie narracyjne wywiady biograficzne i otwarte wywiady pogłębione na temat zachodzących w trakcie życia zmian. Rozmówcami było osiemnaście osób urodzonych między rokiem 1918 a 1942, zamieszkałych obecnie $w$ Warszawie, ale pochodzących $z$ różnych regionów: $z$ Warszawy lub $z$ terenów o niższym standardzie życia przed wojną. Było to trzynaście kobiet i pięciu mężczyzn o zróżnicowanym pochodzeniu społecznym. Należeli do kilku pokoleń kulturowych, wyodrębnionych na podstawie podobnych warunków społeczno-kulturowych w okresie socjalizacji i dojrzewania: (1) pokolenie II RP, które dorosło w okresie międzywojennym; (2) pokolenie wojenne, którego młodość przypadła na okres okupacji; (3) pokolenie ZMP, organizacji masowo indoktrynującej młodzież w okresie powojennym (Szatur-Jaworska 2000); (4) pokolenie opozycji obyczajowej, wkraczające w dorosłość w okresie stalinowskim, ale wyposażone już w podwójną świadomość i poprzez wygląd oraz zachowanie kontestujące ideologię socjalistyczną (Świda-Ziemba 2010); (5) pokolenie odwilży, które dorastało w okresie zmniejszenia terroru po śmierci Stalina (Szatur-Jaworska 2000).

Analiza narracji osób należących do różnych pokoleń i klas społecznych pozwala zaobserwować, że - jak sugerował Elias - wraz ze wzrostem wzajemnych współzależności na poziomie jednostki przetrwania, jaką stanowiło państwo narodowe, zachodziła przemiana struktury psychicznej jednostek. Przejście od obyczaju do mody przyniosło narastającą indywidualizację ze struktur rodowych i rodzinnych, co szło $\mathrm{w}$ parze $\mathrm{z}$ racjonalizacją pod dyscyplinującym dyktatem państwa i kolektywnej ideologii postępu. Następnie przyszła indywidualizacja od tej kolektywnej identyfikacji, co łączyło się ze wzrostem indywidualnej emocjonalności.

\footnotetext{
${ }^{3}$ Mam tu na myśli mechanizm wewnętrzny, psychologiczny, analogiczny do tego, który analizował Colin Campbell (1987), badając genezę nowoczesnego hedonizmu. Już w latach sześćdziesiątych Polacy kierowali się mechanizmem mody, pragnąc naśladować współczesne im, nadchodzące z zewnątrz wzory zachowań. Ze względu na niedoinwestowanie sektora dóbr konsumpcyjnych tylko do pewnego stopnia oznaczało to faktyczny rozwój społecznego naśladownictwa w społeczeństwie, gdyż część towarów była niedostępna. Jednakże Polacy radzili sobie za pomocą tzw. konsumpcji substytutów (zamiast samochodu motocykl), renaturalizacji konsumpcji (szycie modnych sukienek dla samych siebie przez większość kobiet) czy gospodarki nieformalnej (kupowanie na bazarach rzeczy przysyłanych w prywatnych paczkach z zagranicy).
} 


\section{Obyczaj: „Postęp zabija przeszłość”}

Echa przywiązania do obyczaju najsilniej rozbrzmiewają w narracji osób z pokolenia II Rzeczypospolitej i z wyższych warstw społecznych. Najbardziej konsenwentnie stosowały ją dwie kobiety, obie spełniające obydwa kryteria i pochodzące $z$ dawnego zaboru rosyjskiego. U obu pań przeważała identyfikacja rodzinna, rodowa, ważną kategorią była też polskość, ale $z$ ich opowieści wyłania się obraz Polski charakterystyczny dla rodzin inteligenckich i ziemiańskich II RP $-z$ wyraźnym podziałem na elitę, która kształtuje, i lud, który jest edukowany (Świda-Ziemba 2003). Jest to więc raczej Polska ziemiańska, widziana jako sieć rodzin zamieszkałych w poszczególnych powiatach, wybitnych ludzi, działaczy różnych opcji politycznych, niż Polska jako wspólnota wyobrażona złożona $z$ milionów anonimowych obywateli.

W osiemnastym roku sie urodzitam. To jest wszystko, co się dziato od po... od... od odzyskania wolności, to jestem ja. (śmiech) Powstanie późniejsze i wszystko (K, 1918).

Jest to narracja historiocentrycza i rodzinocentryczna, a nie egocentryczna, która przeważa w młodszych pokoleniach (Tarkowska 1985). Narracja biograficzna rozpoczyna się historią rodu osadzoną w wydarzeniach historycznych, które strukturyzują całą opowieść o własnym życiu.

Mój maż byt kuzynem [imię i nazwisko sławnego poety], powiem Pani, jego ojciec byt stryjecznym bratem mego teścia, więc $z$ tej rodziny Kamila. [...] No więc oczywiście prawicówka. Wierzę w Boga. Pacierz dwa razy dziennie mówię. Różaniec w każda niedziele $i$ sobote odmawiam $(\mathrm{K}, 1921)$.

Umiejscowienie społeczne człowieka wyznaczało jego cechy społeczne i wybory: „oczywiście prawicówka”, a nie osobiste „wnętrze”, które domaga się ekspresji. Również codzienne zachowania człowieka $\mathrm{i}$ jego stosunki $z$ innymi nie były regulowane emocjonalną „potrzebą serca”, lecz wynikały z norm obyczajowych, które jasno określały, kto komu co jest winien w ramach istniejących sieci powiązań.

Ja pamiętam, że u nas $w$ rodzinie byli, jak to dawniej się mówito, domownicy tacy. [...] To ja pamiętam jako dziecko, to nie byto mowy, żeby... nie byto to odmienne, jak mnie babcia mówi - weź, weź — jak mnie matka mówi - weź babcię pod rękę i zaprowadź do kościoła. Ja, chociaż miałam jakieśswoje tam po potudniu plany, to odkładałam wszystko, bo ja musiałam pod rękę $z$ ta babcia iść, prawda. Albo tę ciocię przeprowadzić do stotu, bo ona źle chodzita. To $w$ ogóle nie wchodzito $w$ gre jakaś i... zachowanie. A teraz to nie, bo oni maja swój świat $(\mathrm{K}, 1918)$.

Rozmówczyni spostrzega różnicę między normami obyczajowymi a współczesnymi regulatorami zachowań jednostek, które można określić jako indywidualne „widzimisię".

Świat, w którym wychowały się rozmówczynie, przestał istnieć w okresie wojny i okupacji. 
Nie zaczęłam żyć, jak wybuchta wojna. $Z$ bogaczki, najbogatszej panny w trzech woje... powiatach: ostroteckim, ostrowskim i tomżynskim bytam panna. Potem doiłam krowy, świnie chowałam, bośmy gospodarstwo wzięli (K, 1921).

Deklasacja w PRL-u, wyrażona poprzez dojmujący kontrast standardu życia przed i po wojnie, jest głównym motywem tych narracji. W jednym przypadku mąż zginął w obozie koncentracyjnym, a rozmówczyni musiała sama utrzymać matkę i syna, więc okres PRL-u wspomina jako czas wytężonej pracy siedem dni $\mathrm{w}$ tygodniu. $\mathrm{W}$ drugim przypadku mą̇̇ — również z rodziny szlacheckiej - nie chciał się zapisać do partii, co było przyczyną wielokrotnych zwolnień z pracy, musiał więc imać się robót fizycznych, na przykład był furmanem. Rozmówczyni - zgodnie $z$ obyczajowym podziałem pracy między płciami - nie pracowała poza domem, zajmowała się dziećmi i obejściem. Ich sytuacja materialna była trudna, a status społeczny spadt.

Obie rozmówczynie idealizują przeszłość, a na temat nowoczesności wypowiadają się negatywnie albo wyrażają brak zrozumienia zachodzących procesów. Krytyce poddawane są zwłaszcza przemiany religijności i rodziny, czyli sfer najsilniej obwarowanych normami obyczajowymi:

Jestem przerażona rozluźnieniem, brak wiary [...] no i jestem przerażona zachowaniem. Dawniej mężczyzna zdobywat kobietę, a dzisiaj kobiety, ordynarnie Pani powiem, czego nie używam, same rozpinaja rozporki chtopcom, bo widzę na zdjęciach. Te ruchy, te tańce, to wszystko sa sexy, sexy, sexy. A dawniej kobieta byta kimś, on musiat się modlić. Tak jak moja babcia powiedziała: „dzisiaj, dawniej byto tak: adorowat, asystowat, a dopiero potem byli po stowie $i$ dopiero byt ślub". [...] Nic nie poradzimy, ale jestem przerażona po prostu swobo... $i$ wtaściwie kobiety sie wyzwolity. To jest prawdziwe wyzwolenie kobiet. One się do wtadzy pchaja teraz. A te dzieci, a dzieci się co, do żłobka oddaje, do przedszkola, to nie jest to, co matka. Ja swoje sama piersia karmiłam wszystkie $i$ wychowatam (K, 1921).

Rozmówczyni powołuje się na słowa babci, w ogóle w całej narracji odwołuje się do autorytetu starszych od siebie członków własnej rodziny, lokalnej społeczności i wybitnych przedstawicieli polskiego ziemiaństwa. Sama sytuuje się w wiekach obyczaju, dystansując się od współczesności:

Postęp zabija przesztość, to jest normalna rzecz, w tym wchodzi religia $i$ wiara. A ja jestem inne pokolenie (K, 1921).

Można interpretować, że rozmówczynie należą mentalnie do epoki obyczaju. Odwołują się do wartości i norm obyczajowych przedwojennej warstwy ziemiańskiej, czują się częścią tej formacji, uważając, że ich czas już przeminął. Funkcjonują przede wszystkim nie jako odrębne jednostki, ale jako ucieleśnienie wartości swoich rodów i formacji ziemiańskiej. Zgodność z obyczajem jest podstawowym czynnikiem ukierunkowującym zachowanie. 


\section{Postęp: „Musimy iść do przodu!"}

Imperatyw postępu występował w wypowiedziach prawie wszystkich rozmówców. Przytoczone słowa zostały wypowiedziane przez przedstawiciela pokolenia II RP pochodzącego z rodziny robotników rolnych. W wywiadach najstarszych i najmłodszych rozmówców odwołanie do postępu pojawia się sporadycznie i przyjmuje zwykle taką imperatywną i afirmatywną postać. Jest to jak sądzę — rodzaj kalki językowej. Najbardziej konsekwentnie tą kategorią posługują się przedstawiciele pokolenia wojennego i pokolenia ZMP. Ich młodość przypadała na okres budowy tzw. nowego ładu w Polsce, gdy odbudowie kraju i uprzemysłowieniu towarzyszyła intensywna propaganda postępu. W okresie powojennym zwłaszcza młodzież i osoby z tzw. awansu cywilizacyjnego miały nadzieję na budowę sprawnego i zamożnego państwa (Świda-Ziemba 1998).

Najwięcej entuzjazmu wobec idei postępu przejawiało troje spośród moich rozmówców. Kobieta i miężczyzna, którzy pochodzili z rodzin chłopskich, z terenów zacofanych gospodarczo i doświadczyli awansu cywilizacyjnego: oboje znaleźli pracę przy odbudowie kraju - ona w budownictwie, on w wojsku, a następnie ukończyli studia wyższe już w średnim wieku. Ich standard życia w porównaniu do średniej był wysoki. Zawody techniczne i służby mundurowe należały do dobrze opłacanych i mających dobre wsparcie socjalne, czyli dostęp do usług (np. wczasy) i dóbr (służbowe mieszkanie wyposażone w innowacje gospodarstwa domowego). Trzeci w tej grupie rozmówca pochodził z pokolenia wojennego, z rodziny wojskowych osadników na Kresach, wpojono $\mathrm{mu} \mathrm{w}$ domu nacjonalistyczną ideologię. Był przeciwnikiem ustroju socjalistycznego. Doceniał jednak postęp, który się dokonał, gdyż jako inżynier uczestniczył w uprzemysłowieniu kraju:

No, oczywiście, elektryfikacja wptynęta $w$ znacznym stopniu na poziom życia ludzi, tak samo potem, powiedzmy gazyfikacja osiedli, prawda, jak ludzie moga korzystać z elektryczności i gazu do gotowania. To znakomicie utatwito gospodarowanie, ulżyto pracy, w pracy kobietom. Nie musza, powiedzmy, piec chleba, tak jak przedtem na wsi wypiekali, tylko mogą sobie kupić w sklepach spożywczych również chleb (M, 1925).

Narracja na temat postępu budowana jest na kontrastach: lampa naftowa-elektryczność, przechowywanie w piwnicy-lodówki, pranie na tarze-pralki, piece kaflowe-centralne ogrzewanie. Kluczowym elementem w opowieściach jest elektryfikacja - co jest zgodne $z$ indoktrynacją państwa $\mathrm{w}$ okresie powojennym, ale również obiektywnie słuszne, gdyż elektryfikacja umożliwiła automatyzację wielu codziennych czynności.

O ile mężczyźni mówili dość abstrakcyjnie o udogodnieniu w zaspokajaniu potrzeb, o tyle kobiety wskazywały na konkretne praktyki, które przed rewolucją konsumpcyjną w gospodarstwie domowym wymagały znacznego wysiłku fizycznego, zredukowanego dzięki innowacjom. Wynika to zapewne $z$ faktu, że zgodnie $z$ obyczajem prace domowe znajdowały się $\mathrm{w}$ gestii kobiet. 
Bardzo, to znaczy wszystko. Po wojnie mieszkatam w budynku zimnym, no bo to inne tynki, inne wszystko, taki drewniak ładny podwarszawski. Nieogrzewany. Ogrzewanie piecowe, trzeba byto starać się kupić węgiel. A potem go trzeba byto do piwnicy ztadować. Mężczyzn w większości nie byto. Kobiety same chowaty dzieci. I to się pomagało tak sasiadce przywieźć wegiel, to wszyscy nosili, jak do nas przyjechato też wszyscy nosili. Rano wiadomo, żeby napalić $w$ piecu, ile trzeba wcześniej wstać, prawda i żeby to mieszkanie jako tako ciepłe. A ciepto byto tylko przy piecu i nigdzie indziej. Także ja pamiętam lekcje jak odrabiałam, uczytam się oparta o piec, ręce na piecu i tam tu ksiażka i się uczyłam, prawda. A z czasem no mamy centralne, nic nas nie obchodzi (K, 1942).

Czynności związane z zaspokajaniem potrzeb, dziś proste i codzienne, przed rewolucją konsumpcyjną wymagały wysiłku i przygotowań, na przykład mycie się - w warunkach zimna i braku ciepłej wody. W powojennym budownictwie były łazienki, ale w starych kamienicach mieszkańcy instalowali je dzięki własnym staraniom. Matka jednej z rozmówczyń z pokolenia odwilży załatwiła przysposobienie jednego $z$ pomieszczeń na łazienkę. O ile $\mathrm{w}$ tych pokoleniach mycie się służyło zaspokojeniu potrzeby higieny, o tyle dla kolejnych pokoleń — pod wpływem logiki rynku i przekazów medialnych — kąpiel miała być stymulacją przyjemnych emocji. Ten kontrast między racjonalnym zaspokojeniem potrzeby a spełnianiem emocjonalnych pragnień pokazuje cytat:

Grzało się wodę na kuchni, kuchnia była, yyy, nie gazowa. Gaz to dużo później, to palito się pod kuchnia, grzato się wodę i się myliśmy w kuchni - w tazience. [...] Raz na tydzień to byto obowiazzkowe. A mój tata, ponieważ byt starszy pan, [...] tacie nie była łazienka potrzebna. Tata odgarniat sobie koszule, myt se szyje, haha. No, i mama tam załatwita, $\dot{z}$ eby wybudowali nam od pierwszego piętra aż do dachu, pięciopiętrowego budynku komin wentylacyjny, z tej tazienki, żeby piecyk można byto powiesić. Nie byto ogrzewania $w$ tej tazience, więc ojciec jakieścuda robit. Na dole palita się kuchenka gazowa, nad ta kuchenka byt zbiornik $z$ woda $i$ ta woda jakoś tak krążyła tam. [...] Była tazienka. To mój tata mówit tak, jak mieszkała u nas taka młoda dziewczyna, taka w moim wieku, nie, młodsza. To mój tata mówit tak, baletnica czy co, codziennie się myje (K, 1938).

Inżynier z Kresów dystansował się od socjalistycznego przekazu propagandowego, zauważając, że ten sam powojenny postęp dokonał się we wszystkich krajach europejskich:

[...] technika spowodowała ogromne zmiany w życiu ludzi, ułatwiając to życie mieszkańcom zarówno miast $i$ wsi. I to, oczywiście, nie tylko $w$ Polsce, również $w$ innych krajach działo się podobnie. I to trzeba oczywiście uznać jako niewatpliwy postęp i niewatpliwe różnice warunków bytowania ludności poprzednio a obecnie (M, 1925).

Wartości wpisane w tę narrację są kolektywne, dotyczą nie tylko wszystkich mieszkańców Polski, ale również innych krajów, i racjonalne - podkreśla się zmniejszenie wysiłku, ułatwienie, udogodnienie. Narracja ta koncentruje się na potrzebach, a nie na pragnieniach i przyjemności.

Ekscytacja postępem ma swoje granice. Lęk rozmówcy budziło wkraczanie postępu w sferę podziału obowiązków między płciami, którą rządziły normy 
obyczajowe. W tym momencie zaczął posługiwać się narracją przywiązania do obyczaju.

[...] że męska rzecz byto zarobienie na utrzymanie rodziny, a tym samym pozostate obowiazki w domu byty przejmowane przez kobiety [...] (M, 1925).

W imię racjonalnego dążenia do zaspokojenia kolektywnych potrzeb Polacy po wojnie wyzwalali się z lokalnych społeczności i ich obyczajów, wdrażając innowacje i przystosowując się do dyktatu socjalistycznego społeczeństwa nowoczesnego. Było to jednocześnie wyzwolenie z ogromnego trudu codziennego życia. Ideologicznie racjonalizacja własnych działań miała służyć dobru całego społeczeństwa, czyli chodziło o identyfikację kolektywną na wyższym poziomie, inaczej niż w przypadku arystokracji dworskiej, gdy racjonalizacja była instrumentem dbania o własne interesy. Jednocześnie normy obyczajowe i nawyki stawiały opór, gdy w praktykach użytkowania innowacji przemodelowaniu ulegały stosunki rodzinne (zob. Zalewska w druku).

\section{Emocje: „Komuniści się śmiali z tych chuliganów tak zwanych, którzy się modnie ubierają"}

Do pokolenia opozycji obyczajowej należały trzy osoby, pochodzące z inteligencji, które można zaliczyć do „klasy próżniaczej”. Rozmówca płci męskiej - podobnie jak mężowie dwu kobiet - skończył politechnikę, która była enklawą dla osób o nieodpowiednim pochodzeniu. Przyjmowano wszystkich zdolnych, bo było zapotrzebowanie na inżynierów. Później zatrudnienie na stanowiskach specjalistów technicznych dawało pozycję beneficjentów systemu. Wszyscy troje mieli gosposię. W ich kręgu towarzyskim nikt nie musiał zajmować się pracą w domu. Oddawali się ostentacyjnej konsumpcji:

[...] myśmy się dużo bawili. W latach czterdziestych-piećdziesiatych-sześćdziesiątych to żeśmy chodzili na prywatki, różne bale, po lokalach żeśmy chodzili. [...] Prosze pani, na bale chodzito się do opery, do teatru, różne teatry urządzały bale, opera, filharmonia. A jeżeli chodzi o lokale, to najlepszym lokalem byta tzw. Kameralna na Foksal, to byt hotel Grand Hotel na Kruczej, byta restauracja. No i tak się wtaśnie zwiedzało te restauracje właściwie. Dużo żeśmy jeździli na urlopy, na przykład Zakopane. W Zakopanem mamy zaliczone wszystkie bary i restauracje, jakie istniaty i istnieja... no już nie istnieja, bo polikwidowali. W Kazimierzu Dolnym, prosze pani, nad morzem w różnych miejscowościach. Także raczej rozrywkowo się czas spędzato, zreszta mieliśmy bardzo dużo znajomych, którzy tak samo spędzali czas wolny (M, 1928).

Ze względu na szerszą świadomość historyczną i wrogi stosunek do narzuconego siłą systemu Polski Ludowej rozmówca nie był piewcą socjalistycznego postępu. Raczej wytykał systemowi jego wady, porównując go do demokratycznych krajów zachodnich. Nadawał swemu życiu „konsumpcyjny” wymiar już od wczesnej młodości, co było rodzajem buntu, ponieważ propaganda socjalistyczna kojarzyła konsumpcję z Zachodem i upadkiem moralnym. 
No, nie, telewizji wtedy nie byto. Widziatem na ulicy [co jest modne]. I widziałem, $z$ czego się śmieja komuniści. Bo się śmiali $z$ tych chuliganów tak zwanych, którzy się modnie ubieraja. Na przykład nosza skarpetki kolorowe. [I pan nosił?] No oczywiście. Przecież nie będę $w$ czarnych chodzit. Musza być kolorowe... Tu pani trafita, prosze pani, $w$ dziesiątkę. Tak, zwracaliśmy uwagę na ubiór (M, 1928).

Narracja ta ma charakter kolektywny, odwołuje się do wartości wytworzonych przez grupę zawodową i towarzyską, ale jednocześnie zakorzenionych w wartościach przedwojennej warstwy wyższej, z której pochodzili rozmówcy $z$ tej grupy. Rzeczy modne i pożądane to te, które kojarzyły się z Zachodem (kolorowe ubrania) i z przedwojennym porządkiem (solidne materiały). Obydwa skojarzenia były antysystemowe, buntownicze. Konsumpcja miała tu już znaczenie emocjonalne, chodziło o wyrażenie za jej pomocą postawy wewnętrznej. Emocje były zracjonalizowane, wysublimowane, nie prowadziły do aktów agresji, lecz były wyrażane poprzez ubiór.

Jak wspomniał rozmówca, konsumpcja stymulowana emocjami kształtowała się jeszcze zanim upowszechniła się telewizja. Moda rozprzestrzeniała się poprzez kontakty bezpośrednie. W drugiej połowie lat pięćdziesiątych rozmówcy już oglądali telewizję, zwykle u rodziny, sąsiadów lub współlokatorów. $\mathrm{Na}$ początku lat sześćdziesiątych kupowali pierwsze czarno-białe telewizory. Telewizja w latach sześćdziesiątych uczyniła zachodni standard życia niemalże namacalnie bliskim dla każdego. W filmach pokazywano przedmioty i technologie niedostępne w Polsce. Można je było obserwować na wyciągnięcie ręki, ale nie można było doświadczyć. Zapewne ze względu na ową jedynie wirtualną, ale nie rzeczywistą dostępność w okresie młodości pokolenia odwilży „nowości”, jak je nazywano, stanowiły centralny motyw w jego narracjach o zmianach.

Zapytani o luksus wymieniali samochód, telefon, telewizor i pralkę automatyczną. Oczekiwanie na możliwość nabycia tych dóbr, ich kupienie i użytkowanie wiązało się z silnymi emocjami. Tak opisuje rodzaj emocji związanych z kupnem samochodu kobieta - ówcześnie młoda pani inżynier:

No i pierwsze samochody jakie tylko byty, małe fiaty, 69 tysięcy trzeba byto uskładać to tam $z$ każdej premii tam odkładatam pieniądze $i$ dość szybko miatam, bo miałam w 1974 roku pierwszy samochód. No to już byt szat, to już wszędzie swoboda, wolność, wszędzie mogę się poruszyć, o której chcę, gdzie chcę, także to byto fajne (K, 1942).

Podobnie mówi jej koleżanka z pracy:

Ja jeździtam tym maluchem, całowatam go co pięćdziesią kilometrów, bytam tak szczęśliwa, jakby mi ktoś nie wiem co dał. Furę ztota (K, 1938).

Mamy więc kreowanie przyjemnego środowiska dzięki przypisaniu innowacjom silnych emocji. Warto zauważyć, że znaczenia emocjonalne się indywidualizują, nie chodzi już o kolektywny sprzeciw wobec ideologii systemu, ale o indywidualną przyjemność, konkretne odczuwane emocje mogły być w tym przypadku stymulowane amerykańskimi filmami drogi. Oczywiście własny samochód ułatwiał codzienne funkcjonowanie, co było związane z koniecznością 
dalekiego dojazdu do pracy, zaopatrzenia rodziny. Jednakże przeżycie posiadania samochodu $\mathrm{w}$ niewielkim stopniu jest ujmowane $\mathrm{w}$ tych kategoriach, propagowanych przez ideologię postępu. Na pierwszy plan wysuwają się emocje związane z możliwościami radzenia sobie - poczucie swobody, wolności. Szczęście i euforia zaś to dodatkowa korzyść związana ze zdobyciem trudno dostępnego towaru w społeczeństwie niedoboru. Jednakże nie zawsze „bonus” się sprawdzał, niekiedy zbyt długie oczekiwanie sprawiało, że innowacje traciły swoją zdolność stymulacji emocji. Być może wyobraźnia skupiała się już na nowym przedmiocie, moda szła dalej.

[...] bo to $w$ życiu jest tak. Jeśli czegoś bardzo pragniemy, rzeczy $i$, $w$ tym momencie kiedy nam sie wydaje, że potrafimy $z$ tego skorzystać, tego nie mamy $i$ przechodzi jakiś czas $i$ nas na to stać $i$ możemy to mieć, to już nie jest to samo. To już przeszedt ten moment zafascynowania czymś. Na przykład tak miałam z magnetofonem, chciałam bardzo mieć magnetofon. Nie mogłam sobie kupić. Jak już miatam, no, owszem korzystałam, ale to już nie byto to $(\mathrm{K}, 1938)$.

Telefon również wzbudzał silne emocje. Kobieta z klasy robotniczej, kontroler jakości z wykształceniem podstawowym, dokładnie pamięta okoliczności założenia i podłączenia telefonu, ponieważ wydarzeniom tym towarzyszyła silna ekscytacja:

Z tym, że mi zatożyli 20 lipca, to pamiętam jak dziś, to byty moje imieniny, ale podtaczyli mnie dopiero do sieci za miesiac, tak że ja miałam w przedpokoju, gdzie ta szafa stoi, okragty stoliczek $i$ tam ten telefon wtaśnie stat, dwa krzeseteczka $z$ boku, tak jak $w$ pokoiku. I ten telefon właśnie stał, tylko chodzitam $i$ za stuchawkę brałam $i$ czy już sygnat, czy mam sygnat (K, 1936).

Gdy zapytałam, czy dużo się zmieniło, gdy założyli telefon, odparła, że dużo, bo pierwsza $w$ bloku miała telefon. Emocje wiążą się więc $z$ byciem lepszym i wyjątkowym (konsumpcja statusowa), a także $z$ samym obrazem telefonu na stoliczku, a z boku krzesełeczka, czyli odtworzeniem pewnego wyobrażenia rozmówczyni, zapewne pochodzącego $z$ telewizji.

Chciałam tu pokazać, że emocje związane $z$ konsumpcją się indywidualizowały, o ile konsumpcyjny bunt pokolenia opozycji obyczajowej był wyrazem wartości kolektywnych, o tyle emocjonalnie ukierunkowana konsumpcja pokolenia odwilży ma już znaczenie indywidualne.

\section{PODSUMOWANIE: EMOCJE I LUDZKOŚĆ JAKO JEDNOSTKA PRZETRWANIA}

Według Eliasa istnieje współzależność między konfiguracją społeczną a psychiką jednostki, a do kolejnych poziomów integracji społecznej wiedzie proces kształtowania monopolu na danym terytorium. Przedmiotem powyższych rozważań było kształtowanie się podmiotu emocjonalnego, czyli specyficznej struktury psychicznej jednostek i powiązanie tego procesu z powstawaniem 
masowych rynków jako przestrzeni, na której rywalizacja o monopol ekonomiczny się odbywa.

Kształtowanie się emocjonalnego podmiotu było analizowane na przykładzie rozwoju konsumpcji w Polsce Ludowej, od końca drugiej wojny światowej do lat siedemdziesiątych. Ze względu na ustanowienie socjalistycznego ustroju po wojnie jest to przypadek odmienny od kształtowania się rynków masowych w krajach Europy Zachodniej. Jeden monopolista - PRL - zarządzał sferą ekonomiczną, na dodatek zależny był pod tym względem od Związku Radzieckiego. Tuż po wojnie silna była propaganda postępu, która kazała raczej wytłumiać emocje i kierować się racjonalnie określanym dobrem wspólnym (choć $\mathrm{w}$ realizacji tego procesu mogło być wiele nieracjonaności) w sferze konsumpcji i adaptacji innowacji. Chodziło tu o integrację, nie tylko na poziomie państwa, ale nawet na poziomie całej ludzkości, wokół ideałów równości i dobrego poziomu życia dla wszystkich. Co ciekawe, tłumienie emocji występowało również w społeczeństwie dworskim, analizowanym przez Eliasa. Być może kształtowaniu się takiej struktury psychicznej sprzyja istnienie jednego, jasno określonego monopolisty, który posiada zarówno monopol władzy, jak i monopol ekonomiczny.

Konkurencją dla państwowego monopolisty okazały się amerykańskie korporacje, których produkty różnymi kanałami docierały do polskiego odbiorcy, przewyższając jakościowo i wizerunkowo towary rodzime. Przekazy w czasopismach kobiecych, „Przekroju”, filmach amerykańskich pokazywały, jak stymulować emocje w codziennym życiu i jak indywidualne emocje mogą kierować postępowaniem. Sugerowały, że w ten sposób można żyć w lepszym świecie i realizować własne pragnienia. Fala buntu przeciwko systemowi, wyrażana poprzez wygląd i styl życia, była powodowana czynnikami emocjonalnymi. Były to emocje ucywilizowane: wysublimowane w kolorowe skarpetki i konsumpcyjny styl życia. W ten sposób do Polski wkroczyła kultura konsumpcyjna, stanowiąca platformę integracji dzięki mechanizmom rynkowym.

W społeczeństwie rynkowym moda ukształtowała się jako mechanizm złożony. Emocje są barometrem pozwalającym wychwytywać nowe trendy, podpowiadają także jednostkom, które zachowania naśladować. Oparcie procesu naśladownictwa na mechanizmie emocjonalnym umożliwia elastyczność zachowań i łatwość dopasowania w systemie globalnego kapitalizmu. W ten sposób moda oparta na emocjonalnym mechanizmie nowoczesnego hedonizmu umożliwia integrację na poziomie ludzkości jako jednostki przetrwania.

\section{BIBLIOGRAFIA}

Aldridge Alan, 2006, Konsumpcja, tłum. Maciek Żakowski, Sic!, Warszawa.

Appadurai Arjun, 2005, Nowoczesność bez granic. Kulturowe wymiary globalizacji, tłum. Zbigniew Pucek, Universitas, Kraków.

Bauman Zygmunt, 1995, Wieloznaczność nowoczesna, nowoczesność wieloznaczna, tłum. Janina Bauman, Wydawnictwo Naukowe PWN, Warszawa. 
Bauman Zygmunt, 2009, Konsumowanie życia, tłum. Monika Wyrwas-Wiśniewska, Wydawnictwo Uniwersytetu Jagiellońskiego, Kraków.

Campbell Colin, 1987, The Romantic Ethic and the Spirit of Modern Consumerism, Blackwell Publishers, Oxford.

Campbell Colin, 2005, The Desire for the New: Its Nature and Social Location as Presented in Theories of Fashion and Modern Consumerism, w: Roger Silverstone, Eric Hirsch (red.), Consuming Technologies: Media and Information in Domestic Spaces, Routledge, London-New York.

Castells Manuel, 2009, Koniec tysiaclecia, tłum. Janusz Stawiński, Sebastian Szymański, Wydawnictwo Naukowe PWN, Warszawa.

Castells Manuel, 2010, Społeczeństwo sieci, tłum. Mirosława Marody i in., Wydawnictwo Naukowe PWN, Warszawa.

Davies Norman, 1994, Boże igrzysko. Historia Polski, t. 1, tłum. Elżbieta Tabakowska, Znak, Kraków.

De Grazia Victoria, 2005, Irresistible Empire: America's Advance Through Twentieth-century Europe, Harvard University Press, Cambridge, MA.

Elias Norbert, 1939, Über den Prozeß der Zivilisation, Soziogenetische und psychogenetische Untersuchungen, Verlag Haus zum Falken, Basel.

Elias Norbert, 1980, Przemiany obyczajów w cywilizacji Zachodu, tłum. Tadeusz Zabłudowski, PIW, Warszawa.

Elias Norbert, 2006, Mozart. Portret geniusza, tłum. Bogdan Baran, Wydawnictwo W.A.B., Warszawa.

Elias Norbert, 2008, Społeczeństwo jednostek, tłum. Janusz Stawiński, Wydawnictwo Naukowe PWN, Warszawa.

Elias Norbert, 2011, O procesie cywilizacji. Analizy socjo- i psychogenetyczne, tłum. Tadeusz Zabłudowski, Kamil Markiewicz, Wydawnictwo W.A.B., Warszawa.

Gergen Kenneth, 2009, Nasycone Ja. Dylematy tożsamości w życiu wspótczesnym, tłum. Mirosława Marody, Wydawnictwo Naukowe PWN, Warszawa.

Giddens Anthony, 2007, Przemiany intymności. Seksualność, mitość i erotyzm we wspótczesnych spoteczeństwach, tłum. Alina Szulżycka, Wydawnictwo Naukowe PWN, Warszawa.

GUS, 1956, Rocznik statystyczny 1955, Warszawa.

Halawa Mateusz, 2013, Facebook — platforma algorytmicznej towarzyskości i technologia siebie, „Kultura i Społeczeństwo", nr 4.

Hochschild Arlie R., 2009, Zarzadzanie emocjami. Komercjalizacja ludzkich uczuć, tłum. Jacek Konieczny, Wydawnictwo Naukowe PWN, Warszawa.

Illouz Eva, 2009, Emotions, Imagination and Consumption: A New Research Agenda, „Journal of Consumer Culture", t. 9, s. 377-413.

Illouz Eva, 2010, Uczucia $w$ dobie kapitalizmu, tłum. Zygmunt Simbierowicz, Oficyna Naukowa, Warszawa.

Jacyno Małgorzata, 2007, Kultura indywidualizmu, Wydawnictwo Naukowe PWN, Warszawa.

Jaworska Justyna, 2008, Cywilizacja „Przekroju”. Misja obyczajowa w magazynie ilustrowanym, Wydawnictwa UW, Warszawa.

Kaufmann Jean-Claude, 2012, Niezwykła historia szczęśliwej miłości, tłum. Alina Kapciak, Oficyna Naukowa, Warszawa.

Kaufmann Jean-Claude, 2013, Kiedy Ja jest innym. Dlaczego $i$ jak coś się w nas zmienia, tłum. Alina Kapciak, Oficyna Naukowa, Warszawa.

Kłoskowska Antonina, 1964, Kultura masowa, Państwowe Wydawnictwo Naukowe, Warszawa.

Kwaśniewicz Krystyna, 1981, Zwyczaje i obrzędy rodzinne, w: Maria Biernacka, Maria Frankowska, Wanda Paprocka (red.), Etnografia Polski. Przemiany kultury ludowej, t. 2, Ossolineum, Wrocław. 
Lipovetsky Gilles, 1987, L’Empire de l'éphémère: la mode et son destin dans les sociétés modernes, Gallimard, Paris.

Lewicki Mikołaj, 2012, Rozwój gospodarczy i zachowania ekonomiczne, w: Anna Giza, Małgorzata Sikorska (red.), Wspótczesne społeczeństwo polskie, Wydawnictwo Naukowe PWN, Warszawa.

Maffesoli Michel, 2008, Czas plemion. Schytek indywidualizmu w społeczeństwach ponowoczesnych, tłum. Marta Bucholc, Wydawnictwo Naukowe PWN, Warszawa.

Marody Mirosława, 2014, Jednostka po nowoczesnośi. Perspektywa socjologiczna, Scholar, Warszawa.

McKendrick Neil, 1982, The Commercialization of Fashion, w: Neil McKendrick, John Brewer, John Harold Plumb, The Birth of a Consumer Society: The Commercialization of Eighteenth-Century England, Indiana University Press, Bloomington, IN.

McKendrick Neil, Brewer John, Plumb John Harold, 1982, The Birth of a Consumer Society: The Commercialization of Eighteenth-Century England, Indiana University Press, Bloomington, IN.

Okólski Marek, 2002, Przemiany ludnościowe w Polsce w perspektywie minionego stulecia, w: Mirosława Marody (red.), Wymiary życia spotecznego, Scholar, Warszawa.

Olcoń-Kubicka Marta, 2009, Indywidualizacja a nowe formy wspólnotowości, Scholar, Warszawa.

Pleskot Patryk, 2007, Wielki maty ekran. Telewizja a codzienność Polaków w latach sześćdziesiatych, Trio, Warszawa.

Rifkin Jeremy, 2001, Koniec pracy. Schytek sity roboczej na świecie i początek ery postrynkowej, tłum. Ewa Kania, Wydawnictwo Dolnośląskie, Wrocław.

Rifkin Jeremy, 2003, Wiek dostępu. Nowa kultura hiperkapitalizmu, w której ptaci się za każdą chwile życia, tłum. Ewa Kania, Wydawnictwo Dolnośląskie, Wrocław.

Strzyczkowski Konstanty, 2012, Tożsamość w kontekście tendencji rozwojowych spoteczenstwa ponowoczesnego, Wydawnictwa UW, Warszawa.

Szatur-Jaworska Barbara, 2000, Ludzie starzy i starość w polityce społecznej, ASPRA-JR, Warszawa.

Świda-Ziemba Hanna, 1998, „My nowe życie tworzymy i nowy ład”, w: Andrzej Siciński (red.), Do i od socjalizmu, Wydawnictwo Naukowe PWN, Warszawa.

Świda-Ziemba Hanna, 2003, Urwany lot. Pokolenie inteligenckiej młodzieży powojennej $w$ świetle listów i pamiętników z lat 1945-1948, Wydawnictwo Literackie, Kraków.

Świda-Ziemba Hanna, 2010, Mtodzież PRL. Portrety pokoleń $w$ kontekście historii, Wydawnictwo Literackie, Kraków.

Tarkowska Elżbieta, 1985, Zróżnicowanie stylów życia w Polsce: pokolenie i płeć, „Kultura i Społeczeństwo", nr 2.

Tarkowska Elżbieta, 2013, Socjologia kultury wspótczesnej, w: Anna Firkowska-Mankiewicz, Tatiana Kanasz, Elżbieta Tarkowska (red.), Krótkie wykłady z socjologii. Kategorie, problemy, subdyscypliny, Wydawnictwo APS, Warszawa.

Tomaszewski Jerzy, 1996, Dwadzieścia lat niepodległości, w: Antoni Mączak (red.), Od plemion do Rzeczypospolitej, Książka i Wiedza, Warszawa.

Veblen Thorstein, 2008, Teoria klasy próżniaczej, tłum. Janina Frentzel-Zagórska, Muza, Warszawa.

Weber Max, 2011, Etyka protestancka a duch kapitalizmu, tłum. Dorota Lachowska, Wydawnictwa UW, Warszawa.

Wouters Cas, 2004, Sex and Manners: Female Emancipation in the West 1890-2000, Sage, London.

Wouters Cas, 2007, Informalization: Manners and Emotions since 1890, Sage, London.

Zalewska Joanna, w druku, Consumer Revolution in People's Poland: Technologies in Everyday Life and the Negotiation between Custom and Fashion (1945-1980), „Journal of Consumer Culture". 


\section{THE CONSUMER REVOLUTION AND FORMATION OF THE EMOTIONAL SUBJECT FROM THE PERSPECTIVE OF NORBERT ELIAS'S CONCEPT}

\section{Summary}

The aim of this article is to analyze the interdependence between the processes of forming mass markets and the processes of rationalizing emotion and the shaping of modern hedonism. The author uses the perspective of Norbert Elias's process sociology, in which the monopolization of resources results in the growth of dependence between all the inhabitants of the territory encompassed by the monopoly, and this is accompanied by a civilizing process, or the rationalization of the behaviours of individuals. The author presents the idea that the integration process at the level of humanity, as survival unit on the platform of the global market and consumption culture, is ongoing. As an example, the author analyzes the first stage in the consumer revolution in Poland after the Second World War, where fashion was shaped on one side by the socialist ideology of progress, and on the other by the romantic ethic present in communications from the West. Individual emotion as a factor guiding behaviour corresponds to the logic of the market, and fashion is the process of mediating between the market and the individual.

\section{Key words/słowa kluczowe}

Norbert Elias's process sociology / socjologia procesu Norberta Eliasa; monopolization / monopolizacja; rationalization / racjonalizacja; consumer revolution / rewolucja konsumpcyjna; fashion / moda; emotion / emocje; modern hedonism / nowoczesny hedonizm; rationalization of emotions / racjonalizacja emocji 